(c) American Dairy Science Association, 2007.

\title{
Evaluation of Protein Fractionation Systems Used in Formulating Rations for Dairy Cattle
}

\author{
C. Lanzas,${ }^{\star 1}$ L. O. Tedeschi, S. Seo, ${ }^{*}$ and D. G. Fox ${ }^{*}$ \\ *Department of Animal Science, Cornell University, Ithaca, NY 14853 \\ †Department of Animal Science, Texas A\&M University, College Station 77843
}

\begin{abstract}
Production efficiency decreases when diets are not properly balanced for protein. Sensitivity analyses of the protein fractionation schemes used by the National Research Council Nutrient Requirement of Dairy Cattle (NRC) and the Cornell Net Carbohydrate and Protein System (CNCPS) were conducted to assess the influence of the uncertainty in feed inputs and the assumptions underlying the CNCPS scheme on metabolizable protein and amino acid predictions. Monte Carlo techniques were used. Two lactating dairy cow diets with low and high protein content were developed for the analysis. A feed database provided by a commercial laboratory and published sources were used to obtain the distributions and correlations of the input variables. Spreadsheet versions of the models were used. Both models behaved similarly when variation in protein fractionation was taken into account. The maximal impact of variation on metabolizable protein from rumen-undegradable protein (RUP) was 2.5 (CNCPS) and 3.0 (NRC) $\mathrm{kg} / \mathrm{d}$ of allowable milk for the low protein diet, and 3.5 (CNCPS) and 3.9 (NRC) kg/d of allowable milk for the high protein diet. The RUP flows were sensitive to ruminal degradation rates of the B protein fraction in NRC and of the B2 protein fraction in the CNCPS for protein supplements, energy concentrates, and forages. Absorbed Met and Lys flows were also sensitive to intestinal digestibility of RUP, and the CNCPS model was sensitive to acid detergent insoluble crude protein and its assumption of complete unavailability. Neither the intestinal digestibility of the RUP nor the protein degradation rates are routinely measured. Approaches need to be developed to account for their variability. Research is needed to provide better methods for measuring pool sizes and ruminal digestion rates for protein fractionation systems.
\end{abstract}

Key words: modeling, simulation, feed protein fractionation, nutrient supply

Received January 13, 2006.

Accepted August 18, 2006.

${ }^{1}$ Corresponding author: cl272@cornell.edu

\section{INTRODUCTION}

Livestock enterprises are significant contributors to nonpoint sources of environmental $\mathrm{N}$ pollution because of their contributions to ammonia emissions and nitrate contamination of surface and ground water (NRC, 1993, 2003). Purchased feed, especially protein supplements, is a major source of imported nutrients and farm expenses on dairy farms (Klausner et al., 1998). Under these economic and environmental constraints, improving the efficiency of $\mathrm{N}$ utilization and reducing $\mathrm{N}$ excreted are very important to maintain the sustainability of dairy farms, and nutrition models have become an effective farm management tool to accomplish these tasks (Dinn et al., 1998; Wattiaux and Karg, 2004).

Feedstuffs vary widely in NPN, rate and extent of ruminal protein degradation, intestinal digestibility, and essential amino acid (EAA) supply (Broderick et al., 1989; NRC, 2001). Milk production will be reduced when protein supplied by the diet is below energy-allowable milk production, which is affected by protein degradation rates (Fox et al., 2004). Feed protein fractionation systems have been integrated into nutrition models to account for differences in protein availability and utilization. The in situ techniques and schemes based on solubility in buffers and detergent solutions have been adopted by the NRC (2001) and the Cornell Net Carbohydrate and Protein System (CNCPS; Fox et al., 2004) to measure protein fractions in feeds.

Sensitivity analysis identifies key sources of variability and uncertainty and quantifies their contribution to the variance of model outputs (Saltelli, 2000), helping to establish research and data collection priorities for further improvement of nutrition models. Evaluations of the ability of nutrition models to predict duodenal flow of $\mathrm{N}$ and animal performance have been conducted (Kohn et al., 1998; Bateman et al., 2001a,b; NRC, 2001; Fox et al., 2004; Offner and Sauvant, 2004). However, few evaluations based on sensitivity analysis have been conducted. Fox et al. (1995) assessed the impact of feed carbohydrate and protein fractions and microbial composition on animal performance predictions. Tylutki (2002) determined the inputs that routinely need to be analyzed to reduce risk of use of the CNCPS model in 
field conditions. The impact of feed protein variability and model assumptions on MP and AA predicted flows have not been assessed. Reliable predictions of nutrient supply are critical for mathematical models to predict the effects of nutrients absorbed on milk composition and $\mathrm{N}$ efficiency, because any intermediary metabolism model would rely on rumen models for their substrates (Fox et al., 2004; Offner and Sauvant, 2004). The objective of this study was to conduct a series of sensitivity analyses of the protein fractionation schemes of the NRC (2001) and CNCPS (Fox et al., 2004) models to assess their impact on variation in MP and absorbed AA predictions due to feed composition variability. A second objective was to assess the effect of assumptions underlying the CNCPS feed protein fractionation scheme. The overall objective of both analyses was to establish research priorities for increasing the robustness of the models.

\section{MATERIALS AND METHODS}

\section{Protein Fractionation}

The NRC (2001) and the CNCPS (Fox et al., 2004) differ in the schemes used to predict MP and AA supply and requirements. The NRC (2001) adopted the in situ method to partition feed $\mathrm{N}$ fractions into RDP and RUP. The in situ A fraction includes NPN, solubilized protein, and protein in particles smaller than the porosity of the nylon bag. The in situ B fraction is potentially degradable in the rumen, depending on the competition between digestion and passage, and the in situ $\mathrm{C}$ fraction is the unavailable protein, which is estimated as the remaining nitrogen at the end of predetermined incubation time. Intestinal digestibilities of RUP are based on the mobile bag technique (Hvelplund et al., 1992) and in vitro estimates (Calsamiglia and Stern, 1995). A regression approach is used to determine the EAA composition of duodenal protein.

The CNCPS fractionates $\mathrm{N}$ into 5 fractions based on solubility: the A fraction is NPN, the B fraction is true protein, and $\mathrm{C}$ is unavailable protein (Van Soest et al., 1981). The $B$ fraction is further subdivided into 3 fractions (B1, B2, and B3) with different digestion rates. The B1 fraction is soluble in borate phosphate buffer, and is precipitated by TCA. The B3 fraction is insoluble in neutral detergent but is soluble in acid detergent. The $\mathrm{C}$ fraction is insoluble in acid detergent solution. The B2 fraction is calculated by difference. The B fractions are degraded based on the competition between fractional rates of degradation and passage. The A fraction is assumed to be completely degraded, whereas the $\mathrm{C}$ fraction is assumed completely undegraded. Intestinal digestibility is assumed to be $100 \%$ for $\mathrm{B} 1$ and $\mathrm{B} 2$,
Table 1. Diets used in the simulations

\begin{tabular}{ll}
\hline Feeds & $\mathrm{kg}$ of DM/d \\
\hline Feeds in low protein diet & \\
Grass hay & 7.0 \\
Corn silage & 6.0 \\
Dried shelled corn & 4.5 \\
Soybean meal & 0.4 \\
Urea ${ }^{1}$ & 0.2 \\
Feeds in high protein diet & \\
Corn silage & 7.0 \\
High moisture corn grain & 5.5 \\
Alfalfa silage & 4.0 \\
Soybean meal & 2.8 \\
Distillers grains & 2.0 \\
\hline
\end{tabular}

${ }^{1}$ Urea was added when the diet was formulated with the NRC (2001) to supply the required ruminally degraded protein.

$80 \%$ for B3, and $0 \%$ for C. A factorial approach is used to estimate EAA supply (O'Connor et al., 1993).

\section{Sensitivity Analyses}

Animals and Diets. Two scenarios were chosen to test the sensitivity of the models. A low CP diet (12 to $14 \% \mathrm{CP}, 43 \% \mathrm{NDF}$ ) with grass hay and corn silage as forage sources (named the low protein diet) was formulated with each model to meet requirements for $20 \mathrm{~kg}$ of milk/d. A second diet (18\% CP, 30\% NDF) with alfalfa and corn silage as forage sources was formulated with each model to meet requirements for $38 \mathrm{~kg}$ of milk/ $\mathrm{d}$ (named the high protein diet). Both scenarios were chosen because they represent situations in which a lactating dairy cow would likely be responsive to protein. Feedstuffs commonly used in diets of dairy cows in North America (Mowrey and Spain, 1999) were used (Table 1).

Simulation Procedures. Global sensitivity analysis based on Monte Carlo techniques has been used in modeling simulations (Helton and Davis, 2003). In a Monte Carlo analysis, model inputs are described as probability density functions from which samples are drawn to feed the model and derive the probabilities of possible solutions for the model (Law and Kelton, 2000). The Monte Carlo analysis was done with @Risk version 4.5 (Palisade Corp., Newfield, NY) with spreadsheet versions of the CNCPS model as described by Fox et al. (2004) and the NRC model (NRC, 2001). Several sampling techniques that are suitable to Monte Carlo simulation are available. The sampling technique chosen for drawing the samples from the distributions was the Latin Hypercube (McKay et al., 1979). The probability distribution is stratified in the Latin Hypercube sampling. This stratification divides the cumulative curve into intervals of equal probability; from each interval, a sample is randomly taken. Sampling is forced 
to represent values at each interval. Because of the stratification, the Latin Hypercube is more efficient and provides a more stable analysis of the model outcomes than does random sampling (Helton and Davis, 2003). Ten thousand samplings for simulation were carried out. Convergence was set to be less than $1.5 \%$ of change in output statistics; it was achieved in all simulations.

Uncertainty and Sensitivity Measures. The model outputs generated by the simulations are presented as box plots. In a box plot, the box contains the middle $50 \%$ of the data. The middle line in the box represents the median, the upper edge of the box indicates the 75 th percentile, and the lower edge indicates the 25 th percentile. The range between the 75 th and the 25 th percentiles is the interquartile range. The vertical lines extend to a maximum of 1.5 times the interquartile range; the points outside the ends of the vertical lines are outliers. For comparative purposes, the interquartile range was expressed as MP or essential EAA allowable milk, using the efficiency coefficients of MP and EAA utilization of the CNCPS model (Fox et al., 2004).

To relate the variation in the model outputs to the different sources of inputs, a stepwise regression analysis was used. The standard regression coefficients (SRC) were used to rank the inputs. They provide a measure of importance based on the effect of moving each input away from its mean value by a fixed fraction of its SD while retaining all other inputs at their mean values (Helton and Davis, 2002).

To assess differences in precision of the models, Bonferroni confidence intervals were computed for the SD of the simulated outputs (Ott and Longnecker, 2001).

A first series of simulations was conducted to assess the impact of feed protein and EAA composition variability on the $\mathrm{N}$ flows. For each model and scenario, the following simulations were conducted: 1 ) only the $\mathrm{CP}$ values of the feedstuffs were varied; 2 ) the inputs necessary to describe protein fractions and their corresponding rates and intestinal digestibilities were varied; 3) both CP and protein fraction inputs were varied; and 4) EAA composition was varied. The following outputs of the models were assessed: for simulations 1 to 3 , MP from microbial CP (MCP) and RUP, absorbed Lys and Met flows, and for simulation 4, absorbed EAA flows.

To describe inputs as probability density functions (Table 2), a database provided by a commercial laboratory (Dairy One, Ithaca, NY) was used to obtain the feed chemical composition measurements [CP, soluble protein, neutral detergent insoluble CP (NDICP), and neutral detergent insoluble CP (ADICP)]. Feed composition data were fit to a normal distribution. When feed inputs were not statistically normal, the distribution with the best fit to the data was assigned. The goodness of fit was assessed with several statistics ( $\chi^{2}$, Kolmogorov-Smirnov, and Anderson-Darling statistical tests) and graphical methods (distribution function differences plots and probability plots; Law and Kelton, 2000). Minimum and maximum values in the database were used to truncate the distributions and a correlation matrix was incorporated to take into account the correlation among inputs within feed when sampling. For the CNCPS, a normal distribution with a standard deviation proportional to the mean of the degradation rate was used to account for the fact that the variability in the rates estimates increases as the mean value increases for the degradation rates (Weiss, 1994). A triangular distribution was used for the intestinal digestibility coefficients for B1, B2, and B3. For the NRC model, in situ inputs were described as a normal distribution with mean and standard deviations as reported in the NRC (2001). Similarly, the NRC (2001) intestinal RUP digestibilities were also described by triangular distributions.

For the feed EAA composition (Table 3), a normal distribution with mean and standard deviations as reported in the NRC (2001) was used. For the grass hay and alfalfa silage, the NRC data were supplemented with other published sources (Muscato et al., 1983; Tedeschi et al., 2001; Givens and Rulquin, 2004; Ross, 2004) because the NRC database contains single observations. The CNCPS model uses EAA as a percentage of buffer insoluble protein. Muscato et al. (1983) and Tedeschi et al. (2001) concluded that the EAA profile of the original forage could be used to predict the EAA profile of the undegraded intake protein instead of using the buffer insoluble protein profile. Therefore, the EAA profile from the original feedstuff was also used for the CNCPS.

A second series of simulations was conducted to test the sensitivity of the model to the assumptions on $\mathrm{N}$ utilization underlying the solubility based protein fractionation scheme used in the CNCPS as described above. The following assumptions were tested: 1 ) the true soluble protein (B1 fraction) is nearly completely degraded in the rumen, 2) the buffer insoluble CP is composed of 2 kinetically distinct fractions [NDICP corrected for ADICP (B3 fraction), which represents a slowly degradable fraction across feeds, and the B2 fraction that represents an intermediate degradable fraction], and 3) ADICP is assumed to be undegradable in the rumen and indigestible in the small intestine. For testing the assumptions, the following modifications were incorporated into the model spreadsheet and simulations in which $\mathrm{CP}$ and protein composition were varied were carried out:

(1) The degradation rates for B1 fraction were adjusted to available published data, and the frac- 
Table 2. Mean, standard deviations (SD), and distributions for the feeds used in the simulations

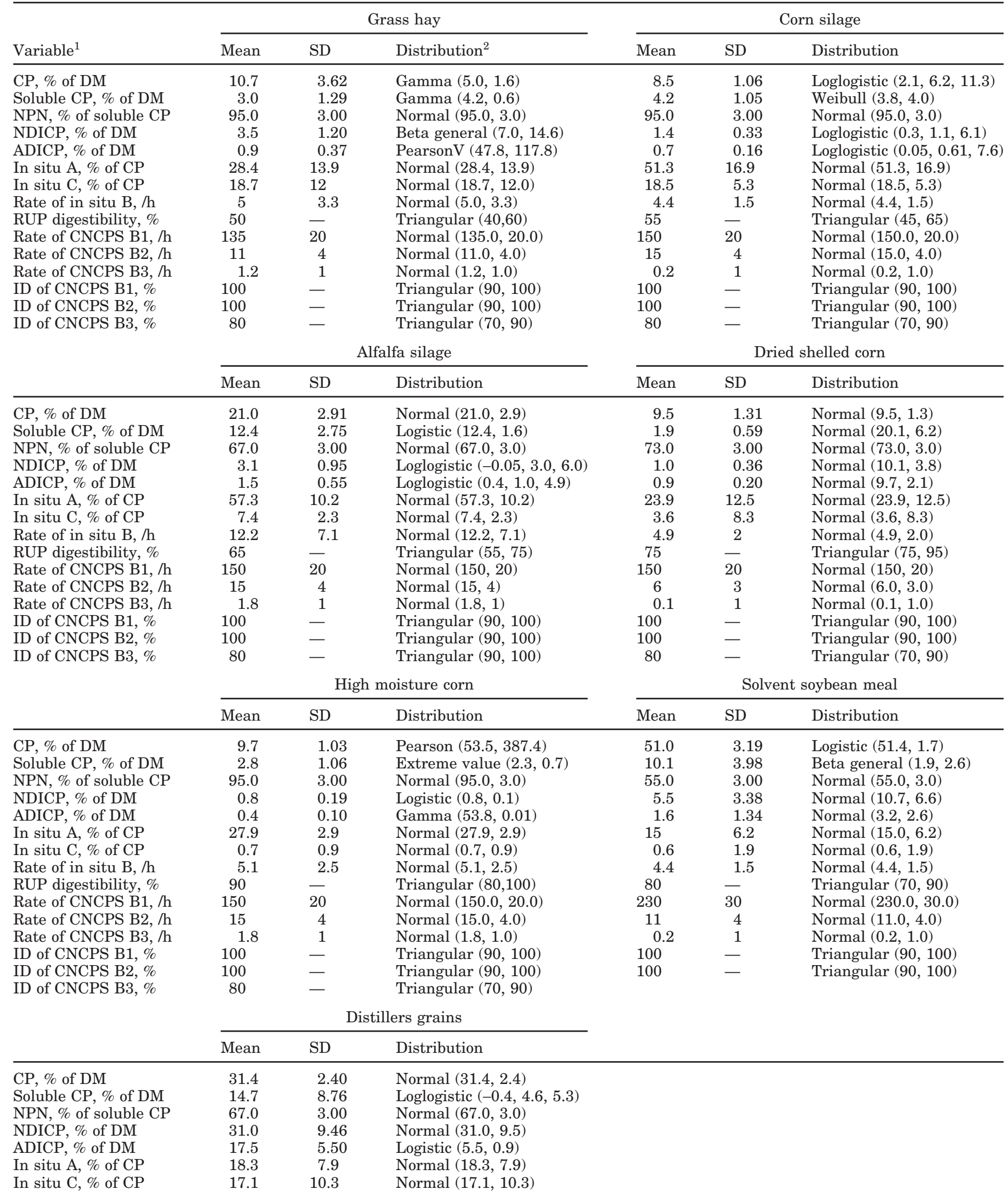


Table 2 (Continued). Mean, standard deviations (SD), and distributions for the feeds used in the simulations

\begin{tabular}{lccl}
\hline & \multicolumn{3}{c}{ Distillers grains } \\
\cline { 2 - 4 } Variable $^{1}$ & Mean & SD & Distribution \\
\hline Rate of in situ B, /h & 4.7 & 1.4 & Normal $(4.7,1.4)$ \\
RUP digestibility, \% & 85 & - & Triangular $(75,95)$ \\
Rate of CNCPS B1, / & 150 & 20 & Normal $(150,20)$ \\
Rate of CNCPS B2, /h & 8 & 3 & Normal $(8.0,3.0)$ \\
Rate of CNCPS B3, /h & 0.5 & 1 & Normal $(0.5,1.0)$ \\
ID of CNCPS B1, \% & 100 & - & Triangular $(90,100)$ \\
ID of CNCPS B2, \% & 100 & - & Triangular $(90,100)$ \\
ID of CNCPS B3, \% & 80 & - & Triangular $(70,90)$ \\
\hline
\end{tabular}

${ }^{1} \mathrm{ADICP}=$ Acid detergent insoluble crude protein; ID = intestinal digestibility; NDICP = neutral detergent insoluble crude protein; $\mathrm{CNCPS}=$ Cornell Net Carbohydrate and Protein System.

${ }^{2}$ The parameters needed to characterize the distribution are indicated in parentheses. An $\alpha$ parameter indicates shape of the distribution, a $\beta$ parameter indicates scale (e.g., $\sigma$ for the normal distribution), and a $\gamma$ parameter indicates location (e.g., $\mu$ for the normal distribution). The distributions are beta general $\left(\alpha_{1}, \alpha_{2}\right)$, extreme value $(\gamma, \beta)$, gamma $(\alpha, \beta)$, logistic $(\alpha, \beta)$, loglogistic $(\gamma, \alpha, \beta)$, normal $(\mu, \sigma)$, PearsonV $(\alpha, \beta)$, and Weibull $(\alpha, \beta)$. The triangular distribution $(\mathrm{a}, \mathrm{b})$ was used in absence of data; $\mathrm{a}$ is the minimum value and $\mathrm{b}$ is the maximum value.

tion was linked to the liquid passage rate. Current feed library values for the degradation rates for the B1 fraction exceed most of the published values for soluble proteins (Mahadevan et al., 1980; Broderick et al., 1989; Peltekova and Broderick, 1996; Hedqvist and Udén, 2006; Table 4).

(2) The impact of assuming 2 potentially degradable fractions within the insoluble protein was tested by collapsing both fractions into a single fraction, with a weighted average degradation rate $(\mathrm{Ta}-$ ble 4).

(3) The effect of partial intestinal digestibility of ADICP of protein supplements on model predictions was assessed by assigning partial digestibilities based on published data (Table 4). For unheated forages, ADICP coefficients of digestion are assumed to be zero (Goering et al., 1972). However, additional ADICP produced by heating was partially digested in steamed treated alfalfa (Broderick et al., 1993), distillers grains (Van Soest, 1989; Nakamura et al., 1994), and plant proteins (Na- kamura et al., 1994; Hussein et al., 1995; Schroeder et al., 1995).

\section{RESULTS AND DISCUSSION}

\section{Sensitivity Analysis 1: Influence of Feed Composition Variation on Model Predictions}

Input Variability. The variability represented is from a broad population of each feedstuff included in the evaluation because feedstuffs were derived from extensive databases. The range in values for the $\mathrm{CP}$ and protein inputs (Table 2 ) were similar to those previously reported for other databases (Kertz, 1998; Cromwell et al., 1999). Table 2 shows the distributions used to describe the feed protein composition. Although the normal distribution was the first choice and the number of samples available to fit the distributions for the chemical protein fractions was in all cases large $(100<$ $\mathrm{n}<1,300$ ), not all the inputs were normally distributed. Some feed components (e.g., ADICP of grass hay and

Table 3. Essential amino acids composition of the feeds used in the simulations (mean \pm SD)

\begin{tabular}{|c|c|c|c|c|c|c|c|c|c|}
\hline Feed & \multicolumn{9}{|c|}{$\mathrm{AA}(\%$ of $\mathrm{CP})$} \\
\hline Alfalfa silage $^{1}$ & $4.1 \pm 0.21$ & $1.7 \pm 0.13$ & $4.2 \pm 0.39$ & $6.8 \pm 0.69$ & $4.6 \pm 0.90$ & $1.2 \pm 0.11$ & $4.4 \pm 0.25$ & $4.0 \pm 0.16$ & $1.9 \pm 0.88$ \\
\hline Distillers grains $^{2}$ & $4.1 \pm 0.28$ & $2.5 \pm 0.21$ & $3.7 \pm 0.13$ & $9.6 \pm 2.80$ & $2.2 \pm 0.39$ & $1.8 \pm 0.21$ & $4.9 \pm 0.37$ & $3.4 \pm 0.34$ & $4.7 \pm 0.27$ \\
\hline Dry corn ${ }^{2}$ & $4.5 \pm 0.05$ & $3.1 \pm 0.05$ & $4.1 \pm 0.04$ & $11.2 \pm 0.14$ & $2.8 \pm 0.03$ & $2.1 \pm 0.02$ & $4.6 \pm 0.05$ & $3.6 \pm 0.03$ & $4.0 \pm 0.04$ \\
\hline Grass hay $^{3}$ & $3.6 \pm 0.59$ & $1.4 \pm 0.25$ & $3.3 \pm 0.63$ & $6.0 \pm 1.26$ & $3.6 \pm 0.68$ & $1.3 \pm 0.46$ & $3.8 \pm 0.75$ & $3.5 \pm 0.78$ & $4.3 \pm 0.92$ \\
\hline $\mathrm{HMCG}^{2,4}$ & $3.9 \pm 0.74$ & $2.5 \pm 0.22$ & $3.4 \pm 0.25$ & $11.6 \pm 0.93$ & $2.6 \pm 0.41$ & $2.1 \pm 0.28$ & $4.6 \pm 0.33$ & $3.7 \pm 0.30$ & $4.9 \pm 0.38$ \\
\hline
\end{tabular}

${ }^{1}$ Givens and Rulquin (2004); NRC (2001); and Ross (2004).

${ }^{2}$ NRC (2001).

${ }^{3}$ Muscato et al. (1983); NRC (2001); Tedeschi et al. (2001).

${ }^{4} \mathrm{HMCG}=$ High moisture corn grain . 
Table 4. Variations in digestion rates $(\mathrm{kd})$ and intestinal digestibilities (ID) used to evaluate assumptions underlying the Cornell Net Carbohydrate and Protein System (CNCPS) protein fractionation scheme

\begin{tabular}{|c|c|c|c|c|c|c|c|}
\hline \multirow[b]{2}{*}{ Feed } & \multicolumn{2}{|c|}{$\begin{array}{c}\mathrm{kd} \text { of CNCPS } \\
\mathrm{B} 1,1 \% / \mathrm{h}\end{array}$} & \multicolumn{2}{|c|}{$\begin{array}{l}\mathrm{kd} \text { of CNCPS } \\
\mathrm{B} 2+\mathrm{B} 3,{ }^{2} \% / \mathrm{h}\end{array}$} & \multicolumn{3}{|c|}{ ID of CNCPS C ${ }^{3}, \%$} \\
\hline & Mean & $\mathrm{SD}$ & Mean & $\mathrm{SD}$ & Mean & Minimum & Maximum \\
\hline Alfalfa silage & 28 & 5 & 10.1 & 4 & - & - & - \\
\hline Corn silage & 28 & 5 & 9.9 & 3 & - & - & - \\
\hline Distillers grains & 50 & 7 & 4.7 & 2 & 30 & 0 & 60 \\
\hline Dried shelled corn & 50 & 7 & 5.7 & 3 & - & - & - \\
\hline Grass hay & 49 & 6 & 4.9 & 2 & - & - & - \\
\hline High moisture corn & 50 & 7 & 8.9 & 3 & - & - & - \\
\hline Soybean meal & 46 & 6 & 9.1 & 3 & 40 & 0 & 80 \\
\hline
\end{tabular}

${ }^{1} \mathrm{~B} 1$ rates are based on several published sources (Broderick et al., 1989; Peltekova and Broderick, 1996; Hedqvist and Udén, 2006).

${ }^{2} \mathrm{~B} 2$ and $\mathrm{B} 3$ rates were collapsed into a single fraction, by assigning the same rate using a weighted average of the original degradation rates.

${ }^{3}$ The intestinal digestibility coefficients (ID) for the $\mathrm{C}$ fraction of protein supplements (triangular distributions) are based on Hussein et al. (1995), Nakamura et al. (1994), Schroeder et al. (1995), and Van Soest (1989).

high-moisture corn grain) had right-skewed distributions (e.g., Pearson and gamma). These skewed distributions have zero as a limit of the function and few observations with high values (Law and Kelton, 2000). Some other inputs (e.g., CP of soybean meal) were narrower around the mean than the normal distribution; thus, they were better represented by log and logistic distributions (Law and Kelton, 2000). This is in agreement with the findings of Kertz (1998), who reported low coefficients of variation $(<2 \%)$ for CP in soybean meal. A consequence of the nonnormality of the feed composition is that the mean and SD are less appropriate as measures of centrality and dispersion of the population (Law and Kelton, 2000). For skewed distributions, the mean overestimates the measure of centrality. Both models are deterministic; in a deterministic model, the solutions of the model represent an average (Baldwin, 1995). However, when variability is taken into account, the mean value of the solutions is not necessary coincident with the deterministic solution (Matis and Tolley, 1980). As the need for reducing safety factors for nutrients increases, accounting for feed composition variability may become more critical.

MCP Predictions. The impact of the protein inputs on MP predictions is shown in Figure 1. Although each diet was formulated for the same MP allowable milk, the models differed in the amounts and proportions that MCP and RUP contributed to MP supply (Figure 1). For comparative purposes, the variation in MP and AA flows was expressed in milk responses using a constant efficiency; it is plausible that this approach overpredicts responses to protein because marginal conversion decreases as supply approaches the requirements (Doepel et al., 2004). Predictions for MCP had different distributions between diets (Figure 1, panels A and
B). The low protein diet had very heavily left-skewed distributions for MCP (Figure 1, panel A). For the NRC predictions, the upper bound corresponded to the maximum RDP requirement. These skewed distributions for both models are due to the discontinuity of the equations used to estimate microbial growth. Both models apply the concept of the limiting nutrient to the prediction of microbial growth, assigning the minimum value between the energy and $\mathrm{N}$-allowable microbial growth (Tedeschi et al., 2000; NRC, 2001). A consequence of this discontinuity may be an increased risk of use of the models when safety factors are reduced for RDP because the accuracy of MCP predictions relies on those inputs that provide fermentable organic matter when energy is first limiting and degradable protein when $\mathrm{N}$ is first limiting (Ruiz et al., 2002). Equations that provide smoother transitions (continuous) from an $\mathrm{N}$ - to energy- limiting (or vice versa) microbial growth would provide more robustness to these models and be more biologically appropriate. The estimation of RDP requirements is an area that needs further refinement in both the NRC and CNCPS models. The inaccuracy in prediction of RDP requirements is well illustrated by Schwab et al. (2005); milk protein yields were predicted better when MP supply was always predicted from available energy, rather than from both available energy and nitrogen. Biases in predicting microbial growth when $\mathrm{N}$ is first limiting may result from not adequately accounting for $\mathrm{N}$ supplied by recycling (both intraruminal and urea recycling), inaccurate predictions of RDP supply, or efficiency of microbial use of $\mathrm{RDP}$. If RDP requirements are overpredicted, the risk of overfeeding RDP and increasing $\mathrm{N}$ excretion increases. If RDP requirements are underpredicted, the risk of not maximizing microbial growth increases. 

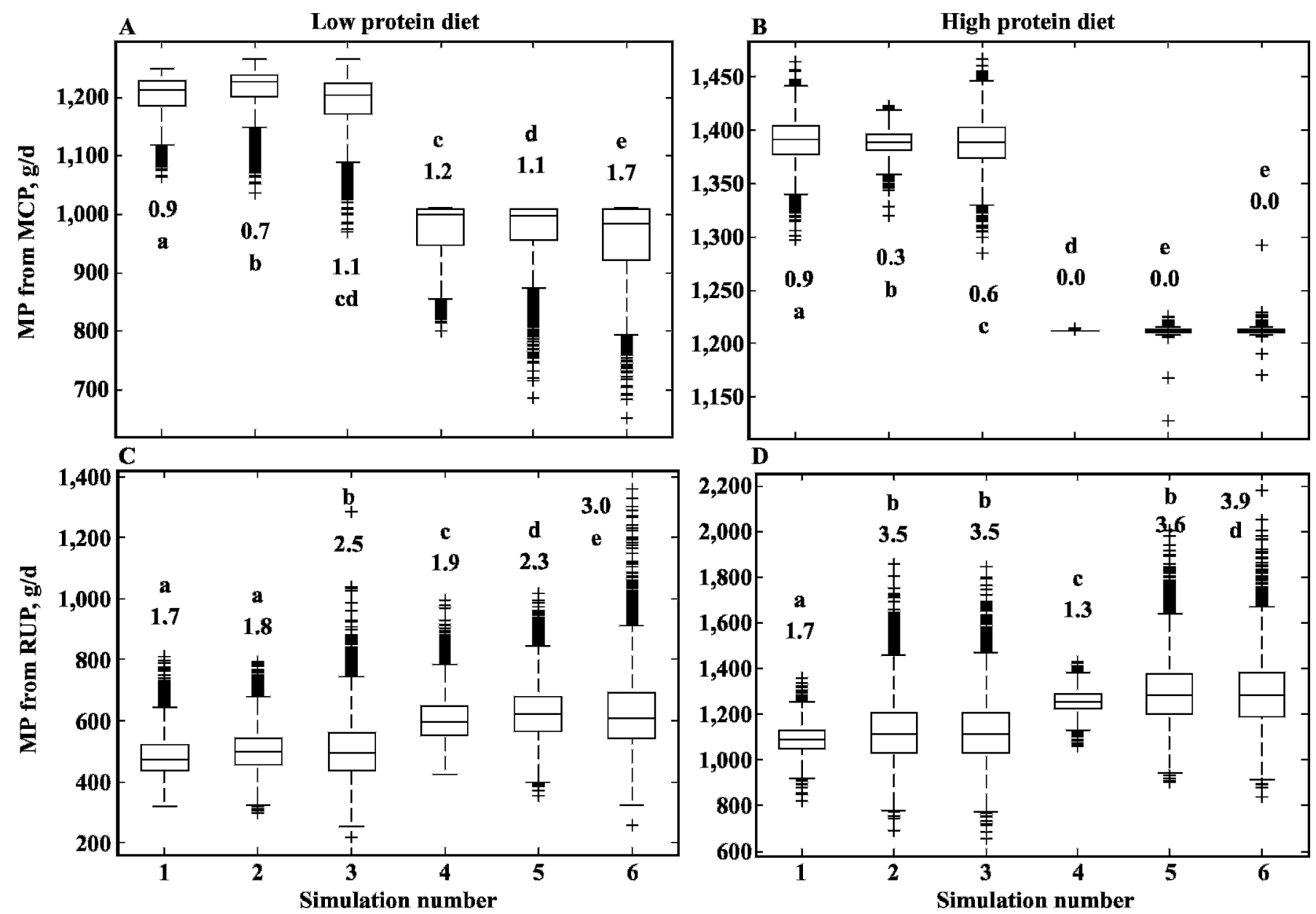

Figure 1. Box plots for the variability in predicted MP from microbial CP: A) low protein diet; B) high protein diet), and from RUP: C) low protein diet; and D) high protein diet due to feed protein variation for the following simulations: 1) Cornell Net Carbohydrate and Protein System (CNCPS), CP; 2) CNCPS, protein fractions; 3) CNCPS, CP and protein fractions; 4) NRC, CP; 5) NRC, protein fractions; and 6) NRC, CP and protein fractions. The middle line in the box represents the median, and upper and lower areas of the center box indicate the 75th and 25th percentiles respectively (50\% of the values are included; the interquartile range $(\mathrm{H})$ is the difference between the 2 percentiles). The whiskers on the lines are extreme values, and indicate values that fall within $1.5 \mathrm{H}$. For comparative purposes, $\mathrm{H}$ is expressed in MP-allowable milk (assuming an efficiency of 0.65). Predictions within a panel with different variance have different letters $(P<0.05)$.

For the high protein diet, the impact of protein variability on MCP predictions of the NRC model was negligible with no predicted milk responses (Figure 1, panel B). At high protein levels, the CNCPS microbial growth predictions were more sensitive to protein (Figure 1, panel B). This is due to the peptide stimulation adjustment factor and the indirect effect that varying protein has on NFC prediction (Fox et al., 2004). Nonfiber carbohydrates are calculated by difference and the amount of carbohydrate fermented in the rumen dictates microbial growth (Fox et al., 2004). The CNCPS adjusts the yield of the bacteria that ferment NSC with an empirical function of amino $\mathrm{N}$ stimulation that enhances microbial yield up to $18 \%$ at any given carbohydrate fermentation rate. Although in vivo responses to amino $\mathrm{N}$ have been variable, improvements in microbial growth and efficiency greater than $18 \%$ have been reported (Hume, 1970; Chikunya et al., 1996). Van Kessell and Russell (1996) demonstrated that peptides and amino acids had little impact on the yield of carbohydrate-limited, ammonia-excess cultures, but they improved the growth rate and yield in excess-energy conditions. Amino- $\mathrm{N}$ helps to match anabolic and catabolic rates, decreasing the waste of energy in spilling reactions (Russell, 1993; Van Kessel and Russell, 1996). Therefore, the sensitivity of microbial growth to protein supply may be overpredicted when the rate of carbohydrate fermentation is low, but may be underpredicted at high fermentation rates (Van Kessel and Russell, 1996). 
A CNCPS model

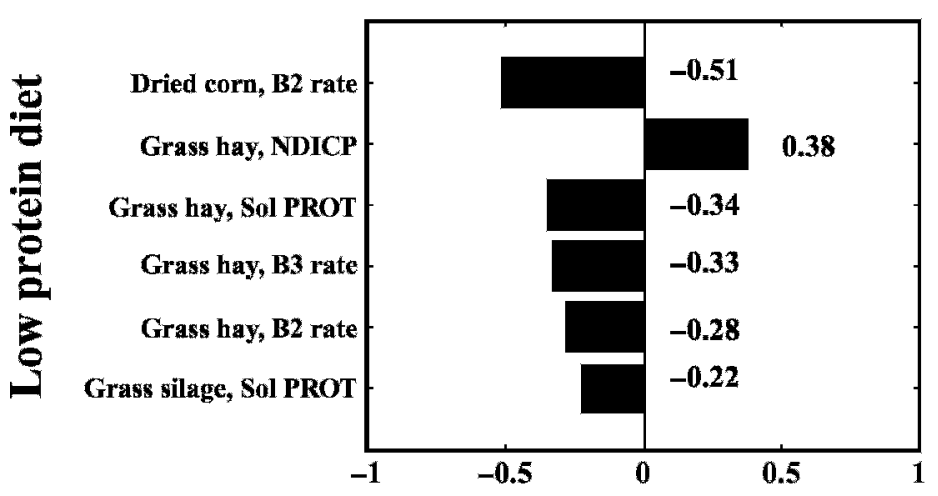

B NRC model

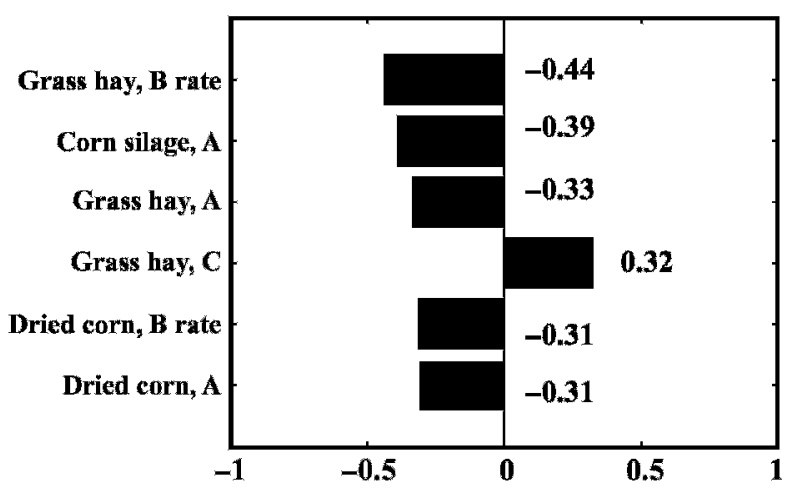

D
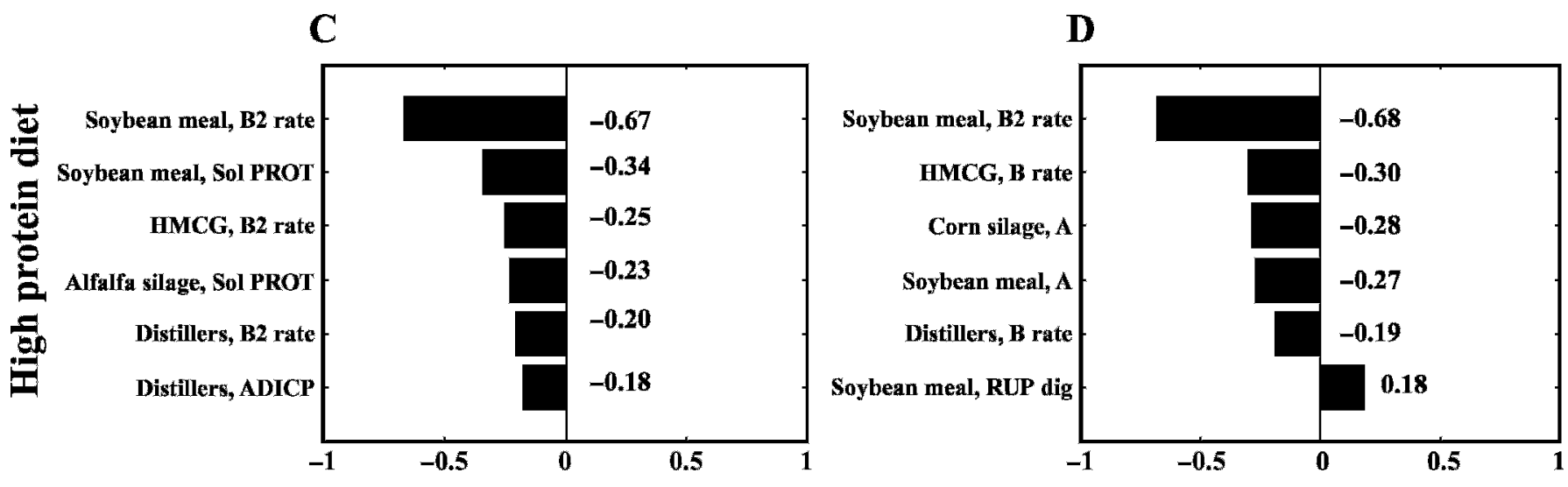

Figure 2. Standard regression coefficients (SRC; $P<0.05$ ) for the protein inputs ranked as the most influential in predicting MP from RUP in the Cornell Net Carbohydrate and Protein System (CNCPS) (panels A and C) and NRC (panels B and D) models. ADICP $=$ acid detergent insoluble crude protein; NDICP = neutral detergent insoluble crude protein; SOL PROT = soluble protein.

MP from RUP. Overall, both models predicted wide ranges in RUP (Figure 1, panels $\mathrm{C}$ and $\mathrm{D}$ ). The standard deviation for predicted RUP within the high protein diet was approximately $200 \mathrm{~g} / \mathrm{d}$ for both models when $\mathrm{CP}$ and protein fractions varied. Ipharraguerre and Clark (2005) summarized intestinal flow data from 57 studies. In their database, a variety of protein sources were represented; DMI ranged from 10.8 to $26.8 \mathrm{~kg} / \mathrm{d}$ and dietary CP ranged from 11.3 to $23.1 \%$. Despite their extensive database, they reported a standard deviation for the nonammonia, nonmicrobial $\mathrm{N}$ intestinal flow of $87.1 \mathrm{~g}$ (544 g of CP), which was only 2.7 -fold greater than models predicted for a single diet. Similarly, in an evaluation of the NRC model, the range in RUP supply was overestimated (Huhtanen, 2005). The protein inputs that contributed the most to the MP from RUP variability are presented in Figure 2. Ruminal degradation rates were highly ranked among the inputs in all the simulations (NRC B rate and CNCPS B2 rate). In the high protein diet, RUP flow was very sensitive to soybean meal rates. In addition, the models were sensitive to protein $B$ fraction degradation rates for energy concentrates (dried corn and high-moisture corn grain) and forages (grass hay and alfalfa silage; Figure 2). Grains provide a substantial amount of protein because their inclusion rate is high in most mixed dairy rations (Mowrey and Spain, 1999). Protein has been described as a first-limiting nutrient for alfalfa silage (Cadorniga and Satter, 1993; Dhiman and Satter, 1993), and grass silage-based rations (Aston et al., 1994). If heated appropriately, RUP content of forages can be increased (Broderick, 1995). Heat treatment at harvest decreased rumen protein degradation and increased the $\mathrm{N}$ of dietary origin flowing to the intestines (Charmley and Veira, 1990). In situ data on protein degradation for grains are limited and in vivo or in vitro data are practically nonexistent (Herrera-Saldana et al., 1990; Lykos and Varga, 1995). The imprecision of the RUP flows may result from the sensitivity of the models to the degradation rates used in the models. With the first-order approach used for both models, the closer the degradation rate is to the passage rate, the 
larger the changes in the model predictions are, with small deviations in the rates. Most of the rates for the in situ B and CNCPS B2 fractions are close to the passage rate predicted by these models (NRC, 2001; Fox et al., 2003). However, Reynal and Broderick (2003) found that the in vivo rates were consistently higher than in vitro and in situ estimates (e.g., for expeller soybean meal, the in vivo rate was $17.9 \% / \mathrm{h}$ whereas the in vitro rate was $4 \% / \mathrm{h}$ ). Thus, in vivo protein degradation rates may be several-fold greater than the passage rate, which may make the RUP flows less sensitive to degradation rates than predicted by the models. Another contributing factor to the imprecision of predicting the RUP flows may be a lack of accuracy of predicted passage rates. Empirical equations used to predict passage rates explained at most $40 \%$ of the variability when evaluated against an independent database (Seo et al., 2006). Methodological factors such as choice of marker and kinetic model may bias the estimates of passage rates. None of the markers are uniformly distributed across digesta phases. Ahvenjärvi et al. (2003) found that $\mathrm{N}$ flowing in the omasal canal was concentrated in small particulate matter. Ytterbium infused in the rumen had greater affinity for small particles (Siddons et al., 1985), and thus, the accuracy of $\mathrm{N}$ flows was linked to the accuracy of ytterbium as a marker (Ahvenjärvi et al., 2003). Reynal and Broderick (2003) obtained rates of passage with ytterbium infused in the rumen of the range of 12 to $14 \% / \mathrm{h}$, whereas rates with ytterbium adsorbed in feed particles were of the range of 2.5 to $6 \% / \mathrm{h}$ (Hristov and Broderick, 1996; Ellis et al., 2002).

The low accuracy and repeatability of the methods used to estimate degradation rates compromise the robustness of the models. The intrinsic limitation of the in situ technique results in consistent underestimation of degradation rates. The loss of particles from the bag underestimates the rate parameter, because the lost particles, which have different chemical composition and surface area than the ones in the bag, generally have faster rates (Noziere and Michalet-Doreau, 2000). In addition, the $\mathrm{N}$ from microbial origin can make up $60 \%$ of the $\mathrm{N}$ in the residue (Beckers et al., 1995), and no procedure completely removes attached microbes (Noziere and Michalet-Doreau, 2000). Similarly, in vitro methods tended to underpredict rate (Reynal and Broderick, 2003). Advances in this area will rely upon a better understanding of the sources of variation in the techniques (Broderick et al., 2004), and greater efforts in modeling and understanding in vitro digestion. Although proteolysis is assumed to be a first-order process, in vitro methods deviate from first-order kinetics for several reasons: 1) substrate-limiting conditions are difficult to maintain through the incubation, 2) when proteolytic enzymes are used, the enzymatic activity may decline over time, and may be subject to end-product inhibition (Broderick and Clayton, 1992; Kohn and Allen, 1995), and 3) microbial growth in a batch follows distinct phases; namely, lag, exponential growth, and stationary phase, that are not observed in vivo.

Along with the problems encountered in estimating digestion and passage rates, the kinetic models used to integrate both passage and digestion (Waldo et al., 1972; Orskov and McDonald, 1979) may be too simplistic to appropriately mimic rumen digestion. Assumptions underlying the models are too restrictive, including the fact that the rumen is assumed to be a single compartment in which materials are mixed instantaneously and completely.

The RUP flows were also sensitive to in situ A and soluble protein fractions (Figure 2). They were negatively linked to RUP supply because both are assumed to be completely degraded in the rumen. High correlations $(\mathrm{r}=0.90)$ have been found for in situ A (soluble in water) and soluble protein measurement (soluble in borate phosphate buffer, fractions A and B1 in CNCPS) because they measure essentially the same protein fraction (Hoffman et al., 1999). For the low protein diet, the RUP flows were also positively related to grass silage NDICP $($ SRC $=0.38)$ and grass silage in situ C $($ SRC $=$ 0.32; Figure 2). For the high protein diet, RUP flows were sensitive to distillers ADICP $(\mathrm{SRC}=-0.18)$ and soybean meal RUP intestinal digestibility $(\mathrm{SRC}=0.18$ ).

Absorbed Met and Lys Flows. Lysine and Met are most frequently the first-limiting EAA for milk production in lactating dairy cows fed corn-based rations (Schwab et al., 1992), and the impact of variability in protein fractionation on their flows is presented in Figures 3 and 4. For the low protein diet, the NRC-predicted flows of Lys and Met were more sensitive to feed variability than were CNCPS predictions because the main contributor was the MCP, which had greater variability for the NRC predictions (Figure 3, panels A and C). The sensitivity in the low protein diet was distributed among several similarly ranked inputs (Figure 4, panels A, B, E, and F). The NRC model was sensitive to those inputs that increase the amount of RDP. Because of the regression approach used in the NRC model to predict AA rumen outflows from feeds, those inputs that increased the main source of MP, MCP for the low protein diet, were positively related to AA flows. An exception was the in situ $\mathrm{C}$ fraction for grass hay. The in situ $\mathrm{C}$ fraction was negatively related with $\mathrm{AA}$ flows $(\mathrm{SRC}=-0.22)$, but it was positively related with MP supply (SRC $=0.32$ ), which suggests a disconnection between the AA and MP predictions. With the factorial approach used in the CNCPS, AA predictions were sensitive to inputs that increase RUP flow or RDP supply 
Low protein diet

High protein diet
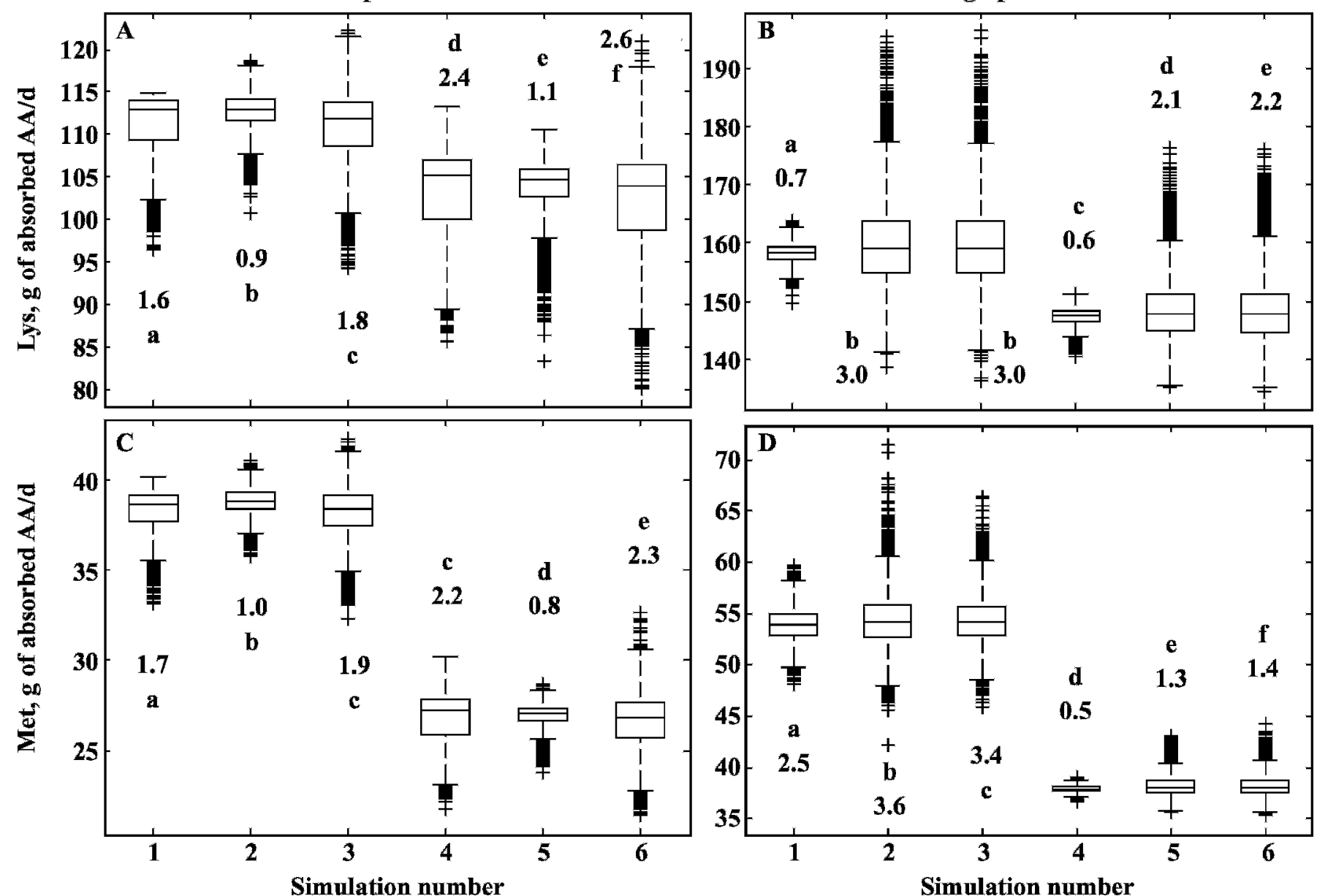

Figure 3. Box plots for the variability in absorbed lysine $(\mathrm{A}=$ low protein diet, $\mathrm{B}=$ silage diet $)$ and methionine $(\mathrm{C}=$ low protein diet, $\mathrm{D}=$ silage diet) predictions due to feed protein variation for the following simulations: 1) Cornell Net Carbohydrate and Protein System (CNCPS), CP; 2) CNCPS, protein fractions; 3) CNCPS, CP and protein fractions; 4) NRC, CP; 5) NRC, protein fractions; and 6) NRC, CP and protein fractions. The middle line in the box represents the median, and upper and lower areas of the center box indicate the 75th and 25 th percentiles respectively ( $50 \%$ of the values are included; the interquartile range $(\mathrm{H})$ is the difference between the 2 percentiles). The whiskers on the lines are extreme values, and indicate values that fall within $1.5 \mathrm{H}$. For comparative purposes, $\mathrm{H}$ is expressed in Lys or Met allowable milk (assuming an efficiency of utilization of 0.82 for Lys and 1 for Met). Predictions within panel with different variance have different letters $(P<0.05)$.

when the diet was deficient in RDP, depending on the AA profile of the feeds. For example, the B2 rate for dried corn was positively related to Lys flows (SRC = $0.30)$ and negatively related to Met flows ( $\mathrm{SRC}=-0.29$ ). The NRC predictions were less sensitive to feed variation with the high protein diet. In the high protein diet (Figure 4, panels $\mathrm{C}, \mathrm{D}, \mathrm{G}$, and $\mathrm{H}$ ), soybean meal B2 rate and in situ $B$ rate were highly ranked for their influence on Lys flows and NRC Met flows. Otherwise, several fractions in various feeds had similar effects on Met and Lys flows. Overall, Met flows were particularly sensitive to intestinal RUP digestibilities (Figure 4, panels E, F, and G) because Met content of the feeds varies considerably (NRC, 2001). The importance of pro- tein intestinal digestibility was highlighted by Noftsger and St-Pierre (2003): when low digestible RUP $(<0.60)$ was replaced by high digestible RUP sources $(>0.90)$, DMI increased by $2 \mathrm{~kg} / \mathrm{d}$ and milk responses as great as $6 \mathrm{~kg} / \mathrm{d}$ were reported. When a low protein $\operatorname{diet}(17 \%$ CP) with a high digestible RUP source was supplemented with Met, DMI increased by less than $1 \mathrm{~kg} / \mathrm{d}$, but milk responses greater than $4 \mathrm{~kg} / \mathrm{d}$ were observed (Noftsger and St-Pierre, 2003).

AA Supply. The EAA composition of feeds and its impact on duodenal flows are presented in Tables 3 and 5, respectively. Despite the statistical differences in their variance, with the exception of the Leu flows and to some extent Thr, EAA flows had numerically 

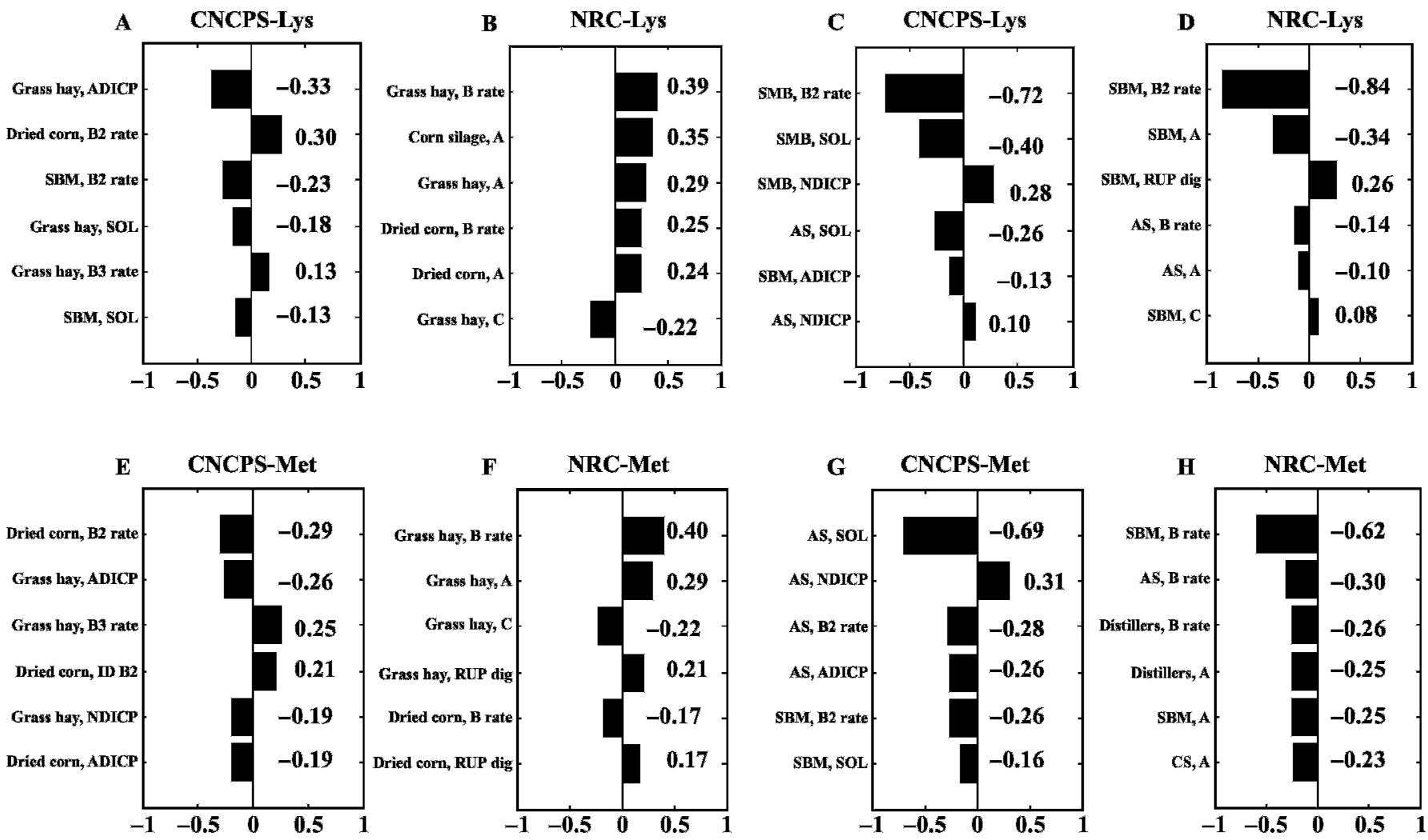

Figure 4. Standard regression coefficients (SRC; $P<0.05)$ for the protein inputs ranked as the most influential in predicting absorbed Lys and Met in the Cornell Net Carbohydrate and Protein System (CNCPS; panels A, C, E, and G) and the NRC (panels B, D, F, and H) models for low and high protein diets. ADICP = acid detergent insoluble crude protein; NDICP = neutral detergent insoluble crude protein; SOL PROT $=$ soluble protein.

similar ranges in EAA-allowable milk, indicating similar sensitivity (Table 5) across the NRC (2001) and CNCPS models and diets. The large responses of milk predicted for some EAA (e.g., Leu) resulted from the use of a constant efficiency of conversion of EAA to milk protein assumed in the models. For the absorbed Lys and Met predictions for both models, the impact of the variation in Lys and Met content (Table 5) was greater than the impact of protein fractions in the low protein diet (Figure 3, panels $\mathrm{A}$ and $\mathrm{C}$ ) and greater than the impact of the CP variation (Figure 3, panels B and D) in the high protein diet.

\section{Sensitivity Analysis 2: Impact of Assumptions Underlying the CNCPS Protein Fractionation Scheme}

Table 6 summarizes the results of the evaluations of CNCPS protein digestion rates and ADICP digestibility. The MP supply was rather insensitive to changes in the assumptions underlying the fractionation scheme. The changes in predicted allowable milk were less than
$0.5 \mathrm{~kg}$ of milk/d. The Met and Lys flows were more sensitive to changes in the assumptions.

Soluble Protein Degradation. Degradation rates for the B1 fraction were reduced to reflect available published data (Table 4) and integrated with liquid rather than particle passage rate as assumed in the CNCPS. The MP supply for both diets was insensitive to these changes, because the B1 fraction represented a small proportion of the total protein supply $(<8 \%$ of the total $\mathrm{CP}$ ). Although the rates were lowered, they were still much greater than the liquid passage rates predicted by the CNCPS passage rate equations $(9.8 \% /$ $\mathrm{h}$ for the low protein diet and $11.8 \% / \mathrm{h}$ for the high protein diet), which resulted only in small changes in extent of B1 degradation. In vivo studies have shown similar effects. When Choi et al. (2002) supplemented a grass silage-based diet with protein concentrates with high and low in situ A fractions, soluble nonamino $\mathrm{N}$ omasal flow was not significantly different among treatments. However, these modifications resulted in an increase in the Lys and Met flows, especially for the high protein diet (Table 6), because Lys and Met flows were 
Table 5. Variation in absorbed essential amino acids (EAA) due to variability in EAA composition of the feeds $^{1,2}$

\begin{tabular}{|c|c|c|c|c|c|c|c|c|}
\hline \multirow[b]{2}{*}{$\mathrm{AA}$} & \multicolumn{2}{|c|}{ Low protein, CNCPS } & \multicolumn{2}{|c|}{ Low protein, NRC } & \multicolumn{2}{|c|}{ High protein, CNCPS } & \multicolumn{2}{|c|}{ High protein, NRC } \\
\hline & $\begin{array}{l}\text { Mean } \\
(\mathrm{g} / \mathrm{d})\end{array}$ & $\begin{array}{l}\text { EAA allowed } \\
(\mathrm{kg} \text { of milk/d) }\end{array}$ & $\begin{array}{l}\text { Mean } \\
(\mathrm{g} / \mathrm{d})\end{array}$ & $\begin{array}{l}\text { EAA allowed } \\
(\mathrm{kg} \text { of milk/d) }\end{array}$ & $\begin{array}{l}\text { Mean } \\
(\mathrm{g} / \mathrm{d})\end{array}$ & $\begin{array}{l}\text { EAA allowed } \\
(\mathrm{kg} \text { of milk/d) }\end{array}$ & $\begin{array}{l}\text { Mean } \\
(\mathrm{g} / \mathrm{d})\end{array}$ & $\begin{array}{l}\text { EAA allowed } \\
(\mathrm{kg} \text { of milk/d) }\end{array}$ \\
\hline Arg & 106 & $1.0^{\mathrm{b}}$ & 79 & $0.9^{c}$ & 155 & $1.2^{\mathrm{a}}$ & 115 & $0.8^{d}$ \\
\hline His & 44 & $0.8^{\mathrm{d}}$ & 36 & $1.3^{\mathrm{c}}$ & 65 & $1.6^{\mathrm{a}}$ & 54 & $1.6^{\mathrm{b}}$ \\
\hline Ile & 91 & $1.3^{\mathrm{b}}$ & 86 & $1.8^{\mathrm{a}}$ & 126 & $1.3^{\mathrm{c}}$ & 119 & $1.3^{\mathrm{d}}$ \\
\hline Leu & 133 & $2.7^{\mathrm{d}}$ & 153 & $4.1^{\mathrm{c}}$ & 200 & $8.2^{\mathrm{b}}$ & 215 & $8.9^{\mathrm{a}}$ \\
\hline Lys & 122 & $1.7^{\mathrm{d}}$ & 122 & $2.1^{\mathrm{c}}$ & 160 & $2.3^{\mathrm{a}}$ & 154 & $2.2^{\mathrm{b}}$ \\
\hline Met & 44 & $1.4^{\mathrm{c}}$ & 33 & $2.0^{\mathrm{a}}$ & 60 & $1.9^{b}$ & 44 & $1.2^{\mathrm{d}}$ \\
\hline Phe & 85 & $2.2^{\mathrm{b}}$ & 84 & $1.9^{\mathrm{c}}$ & 125 & $2.3^{\mathrm{a}}$ & 125 & $1.6^{\mathrm{d}}$ \\
\hline Thr & 86 & $1.8^{\mathrm{b}}$ & 86 & $3.1^{\mathrm{a}}$ & 119 & $1.5^{\mathrm{d}}$ & 117 & $1.7^{\mathrm{c}}$ \\
\hline Val & 97 & $1.7^{\mathrm{b}}$ & 95 & $1.9^{\mathrm{a}}$ & 136 & $1.9^{\mathrm{a}}$ & 134 & $1.3^{\mathrm{c}}$ \\
\hline
\end{tabular}

${ }^{\mathrm{a}-\mathrm{d}}$ Predictions with different variance within row have different superscripts $(P<0.05)$.

${ }^{1}$ Difference between the 75 th and 25 th percentiles are expressed in EAA-allowable milk.

${ }^{2}$ CNCPS $=$ Cornell Net Carbohydrate and Protein System; NRC = NRC (2001) model.

more sensitive to the variation in $\mathrm{B} 1$ fraction than total RUP flows (Figure 2, panel $\mathrm{C}$ and Figure 4, panels C and G). Assuming constant efficiencies, the increase in Lys and Met were predicted to increase milk (Table 6).

Degradation Rates for Insoluble Protein. The collapse of the fractions B2 and B3 had a greater effect on the RUP flows for the low protein diet, because the B3 fraction represents a greater proportion of the total protein. The assigned degradation rates for the B fraction were based on the number of pools and rates identified by the curve peeling technique described by Jacquez (1985), using data from in vitro incubations with protease from Streptomyces griseus (Pichard, 1977). The low rates for the protein B3 fraction are not always supported by the data (Coblentz et al., 1999; Lagunes et al., 1999). Because the curve peeling approach causes the errors to propagate from the slow component into the faster components (Jacquez, 1985), protein B2 rates may have also been inaccurately estimated. The partition of the insoluble protein into 2 distinguishable fractions may not be necessary.

Partial Intestinal Digestibility of ADICP. Assuming partial intestinal digestibility of the ADICP fraction in protein supplements (distillers grains and soybean meal) had a similar impact on Lys and Met flows to the previously tested assumptions. These results are consistent with the observation that Lys and Met flows were very sensitive to intestinal digestibilities. Because no data were available on ruminal fraction digestion rates of ADICP, the impact of partial ruminal

Table 6. Impact of varying the assumptions underlying the Cornell Net Carbohydrate and Protein System (CNCPS) protein fractionation scheme on model predictions ${ }^{1}$

\begin{tabular}{|c|c|c|c|c|c|c|c|}
\hline \multirow[b]{2}{*}{ Diet } & \multirow{2}{*}{$\frac{\text { Base }}{\text { Mean }(\mathrm{g} / \mathrm{d})}$} & \multicolumn{2}{|c|}{ Lower $^{2} \mathrm{~B} 1$ rates } & \multicolumn{2}{|c|}{$\begin{array}{c}\text { Collapsed B2 and B3 } \\
\text { fractions }^{3}\end{array}$} & \multicolumn{2}{|c|}{$\begin{array}{l}\text { Partial ID for C } \\
\text { fraction }^{4}\end{array}$} \\
\hline & & $\mathrm{g} / \mathrm{d}$ & $\begin{array}{l}\mathrm{kg} \text { of } \\
\mathrm{milk} / \mathrm{d}\end{array}$ & $\mathrm{g} / \mathrm{d}$ & $\begin{array}{l}\mathrm{kg} \text { of } \\
\mathrm{milk} / \mathrm{d}\end{array}$ & $\mathrm{g} / \mathrm{d}$ & $\begin{array}{l}\mathrm{kg} \text { of } \\
\mathrm{milk} / \mathrm{d}\end{array}$ \\
\hline \multicolumn{8}{|l|}{ Low protein diet } \\
\hline MP from microbial $\mathrm{CP}$ & 1,194 & -4 & 0 & -4 & 0 & - & - \\
\hline MP from RUP & 504 & 11 & 0.2 & -22 & -0.4 & 0 & 0 \\
\hline Absorbed Lys & 111 & 1 & 0.4 & 2 & 0.8 & 1 & 0.4 \\
\hline Absorbed Met & 38 & 1 & 1.2 & 1 & 1.2 & 1 & 1.2 \\
\hline \multicolumn{8}{|l|}{ High protein diet } \\
\hline MP from microbial $\mathrm{CP}$ & 1,388 & 0 & 0 & 1 & 0 & - & - \\
\hline MP from RUP & 1,127 & -2 & 0 & -5 & -0.1 & 0 & 0 \\
\hline Absorbed Lys & 160 & 4 & 1.6 & 2 & 0.8 & 2 & 0.8 \\
\hline Absorbed Met & 54 & 3 & 3.5 & 1 & 1.2 & 1 & 1.2 \\
\hline
\end{tabular}

${ }^{1}$ The change in the model predictions (prediction with the modified assumption - base prediction) are expressed as $\mathrm{g} / \mathrm{d}$ and allowable milk.

${ }^{2}$ The degradation rates for the CNCPS B1 fraction were adjusted to available published data, and the fraction was linked to the liquid passage rate.

${ }^{3} \mathrm{~B} 2$ and B3 fractions were collapsed into a single fraction, with a weighted average degradation rate.

${ }^{4}$ Partial intestinal digestibility coefficients (ID) for the $\mathrm{C}$ fraction of protein supplements were assigned. 
digestion of ADICP could not be assessed. However, Hussein et al. (1995) found that ADICP from roasted soybean meals were partially digested in both the rumen and small intestine. Some of the components recovered in the ADICP fraction may be Maillard products from the early stages of the reaction that are available.

\section{CONCLUSIONS}

Sensitivity analysis can be used to prioritize protein fraction analysis and to identify research priorities to improve nutritional models for accurately predicting MP and AA supply. Despite the differences in the protein schemes, both NRC and CNCPS predictions of MP supply were similar in sensitivity to variation in protein fractions and their degradation rates because of the use of common principles, such as the competition between digestion and passage to predict site of digestion and the first-limiting nutrient to estimate microbial growth. Metabolizable protein and AA flows were sensitive to the degradation rates of the $\mathrm{B}$ protein fraction in the $\mathrm{NRC}$ and the B2 fraction in the CNCPS and intestinal digestibilities. Neither the degradation rates nor the intestinal digestibilities are routinely measured. In addition, the low accuracy of in vitro and in situ degradation rates may cause an overprediction of the ranges in RDP-RUP flows. Both laboratory methods and a better approach to integrate protein degradation rates are necessary. Although predicted flows for diets with supplemented protein were very sensitive to the feed inputs of the supplements, decreasing the supplemented protein resulted in an increase of the number of inputs that needed to be measured. As the protein levels of the diets decrease, more data are needed on protein fractionation and their digestion rates for forages and energy supplements, because forages and energy supplements represent the largest proportion of MP derived from the diet.

\section{REFERENCES}

Ahvenjärvi, S., A. Vanhatalo, K. J. Shingfield, and P. Huhtanen. 2003. Determination of digesta flow entering the omasal canal of dairy cows using different marker systems. Br. J. Nutr. 90:41-52.

Aston, K., C. Thomas, S. R. Daley, and J. D. Sutton. 1994. Milk production from grass silage diets-Effects of the composition of supplementary concentrates. Anim. Prod. 59:335-344.

Baldwin, R. L. 1995. Modeling ruminant digestion and metabolism. Chapman \& Hall, London, UK.

Bateman, H. G., J. H. Clark, R. A. Patton, C. J. Peel, and C. G. Schwab. 2001a. Prediction of crude protein and amino acid passage to the duodenum of lactating cows by models compared with in vivo data. J. Dairy Sci. 84:665-679.

Bateman, H. G., II, J. H. Clark, R. A. Patton, C. J. Peel, and C. G. Schwab. 2001b. Accuracy and precision of computer models to predict passage of crude protein and amino acids to the duodenum of lactating cows. J. Dairy Sci. 84:649-664.

Beckers, Y., A. Thewis, B. Maudoux, and E. Francois. 1995. Studies on the in situ nitrogen degradability corrected for bacterial con- tamination of concentrate feeds in steers. J. Anim. Sci. 73:220227.

Broderick, G. A. 1995. Desirable characteristics of forage legumes for improving protein utilization in ruminants. J. Anim. Sci. 73:2760-2773.

Broderick, G. A., and M. K. Clayton. 1992. Rumen protein degradation rates estimated by nonlinear-regression analysis of MichaelisMenten in vitro data. Br. J. Nutr. 67:27-42.

Broderick, G. A., P. Uden, M. L. Murphy, and A. Lapins. 2004. Sources of variation in rates of in vitro ruminal protein degradation. J. Dairy Sci. 87:1345-1359.

Broderick, G. A., R. J. Wallace, and E. R. Orskov. 1989. Control of rate and extent of protein degradation. Pages 541-592 in Physiological aspects of digestion and metabolism in ruminants. T. Tsuda, Y. Sasaki, and R. Kawashima, ed. Academic Press, Inc., San Diego, CA.

Broderick, G. A., J. H. Yang, and R. G. Koegel. 1993. Effect of steam heating alfalfa hay on utilization by lactating dairy cows. J. Dairy Sci. 76:165-174.

Cadorniga, C., and L. D. Satter. 1993. Protein versus energy supplementation of high alfalfa silage diets for early lactation cows. J. Dairy Sci. 76:1972-1977.

Calsamiglia, S., and M. D. Stern. 1995. A 3-step in vitro procedure for estimating intestinal digestion of protein in ruminants. J. Anim. Sci. 73:1459-1465.

Charmley, E., and D. M. Veira. 1990. Inhibition of proteolysis at harvest using heat in alfalfa silages: Effects on silage composition and digestion by sheep. J. Anim. Sci. 68:758-766.

Chikunya, S., C. J. Newbold, L. Rode, X. B. Chen, and R. J. Wallace. 1996. Influence of dietary rumen-degradable protein on bacterial growth in the rumen of sheep receiving different energy sources. Anim. Feed Sci. Technol. 63:333-340.

Choi, C. W., A. Vanhatalo, S. Ahvenjärvi, and P. Huhtanen. 2002 Effects of several protein supplements on flow of soluble nonammonia nitrogen from the forestomach and milk production in dairy cows. Anim. Feed Sci. Technol. 102:15-33.

Coblentz, W. K., J. O. Fritz, W. H. Fick, R. C. Cochran, J. E. Shirley, and J. E. Turner. 1999. In situ disappearance of neutral detergent insoluble nitrogen from alfalfa and eastern gamagrass at three maturities. J. Anim. Sci. 77:2803-2809.

Cromwell, G. L., C. C. Calvert, T. R. Cline, J. D. Crenshaw, T. D. Crenshaw, R. A. Easter, R. C. Ewan, C. R. Hamilton, G. M. Hill, A. J. Lewis, D. C. Mahan, E. R. Miller, J. L. Nelssen, J. E. Pettigrew, L. F. Tribble, T. L. Veum, and J. T. Yen. 1999. Variability among sources and laboratories in nutrient analyses of corn and soybean meal. J. Anim. Sci. 77:3262-3273.

Dhiman, T. R., and L. D. Satter. 1993. Protein as the first-limiting nutrient for lactating dairy cows fed high proportions of good quality alfalfa silage. J. Dairy Sci. 76:1960-1971.

Dinn, N. E., J. A. Shelford, and L. J. Fisher. 1998. Use of the Cornell Net Carbohydrate and Protein System and rumen-protected lysine and methionine to reduce nitrogen excretion from lactating dairy cows. J. Dairy Sci. 81:229-237.

Doepel, L., D. Pacheco, J. J. Kennelly, M. D. Hanigan, I. F. Lopez, and H. Lapierre. 2004. Milk protein synthesis as a function of amino acid supply. J. Dairy Sci. 87:1279-1297.

Ellis, W. C., M. J. Wylie, and J. H. Matis. 2002. Validity of specifically applied rare earth elements and compartmental models for estimating flux of undigested plant tissue residues through the gastrointestinal tract of ruminants. J. Anim. Sci. 80:2753-2758.

Fox, D. G., M. C. Barry, R. E. Pitt, D. K. Roseler, and W. C. Stone. 1995. Application of the Cornell Net Carbohydrate and Protein model for cattle consuming forages. J. Anim. Sci. 73:267-277.

Fox, D. G., L. O. Tedeschi, T. P. Tylutki, J. B. Russell, M. E. Van Amburgh, L. E. Chase, A. N. Pell, and T. R. Overton. 2004. The Cornell Net Carbohydrate and Protein System model for evaluating herd nutrition and nutrient excretion. Anim. Feed Sci. Technol. 112:29-78.

Fox, D. G., T. P. Tylutki, L. O. Tedeschi, M. E. Van Amburgh, L. E. Chase, A. N. Pell, T. R. Overton, and J. B. Russell. 2003. The net carbohydrate and protein system for evaluating herd nutrition 
and nutrient excretion: Model documentation, Mimeo No. 213. Animal Science Dept., Cornell University, Ithaca, NY.

Givens, D. I., and H. Rulquin. 2004. Utilisation by ruminants of nitrogen compounds in silage-based diets. Anim. Feed Sci. Technol. 114:1-18.

Goering, H. K., P. J. Van Soest, L. W. Smith, D. R. Waldo, C. H. Gordon, and R. W. Hemken. 1972. Analytical estimates of nitrogen digestibility in heat damaged forages. J. Dairy Sci. 55:1275-1280.

Hedqvist, H., and P. Udén. 2006. Measurement of soluble protein degradation in the rumen. Anim. Feed Sci. Technol. 126:1-21.

Helton, J. C., and F. J. Davis. 2002. Illustration of sampling-based methods for uncertainty and sensitivity analysis. Risk Anal. 22:591-622.

Helton, J. C., and F. J. Davis. 2003. Latin hypercube sampling and the propagation of uncertainty in analyses of complex systems. Reliab. Eng. Syst. Safe. 81:23-69.

Herrera-Saldana, R., J. T. Huber, and M. H. Poore. 1990. Dry matter, crude protein, and starch degradability of five cereal grains. J. Dairy Sci. 73:2386-2393.

Hoffman, P. C., N. M. Brehm, L. M. Bauman, J. B. Peters, and D. J. Undersander. 1999. Prediction of laboratory and in situ protein fractions in legume and grass silages using near-infrared reflectance spectroscopy. J. Dairy Sci. 82:764-770.

Hristov, A., and G. A. Broderick. 1996. Synthesis of microbial protein in ruminally cannulated cows fed alfalfa silage, alfalfa hay, or corn silage. J. Dairy Sci. 79:1627-1637.

Huhtanen, P. 2005. A review of the 2001 dairy cattle NRC protein and amino acid model-A European perspective. J. Dairy Sci. 88(Suppl. 1):88. (Abstr.)

Hume, I. D. 1970. Synthesis of microbial protein in the rumen. III. The effect of dietary protein. Aust. J. Agric. Res. 21:305-314.

Hussein, H. S., B. Demjanec, N. R. Merchen, and C. G. Aldrich. 1995. Effect of roasting on site and extent of digestion of soybean meal by sheep: II. Digestion of artifacts of heating. J. Anim. Sci. $73: 835-842$.

Hvelplund, T., M. R. Weisbjerg, and L. S. Andersen. 1992. Estimation of the true digestibility of rumen undegraded dietary protein in the small intestine of ruminants by the mobile bag technique. Acta Agric. Scand. A, Anim. Sci. 42:34-39.

Ipharraguerre, I. R., and J. H. Clark. 2005. Impacts of the source and amount of crude protein on the intestinal supply of nitrogen fractions and performance of dairy cows. J. Dairy Sci. 88(E. Suppl.):E22-E37.

Jacquez, J. A. 1985. The inverse problem: Parameter estimation. Pages 311-353 in Compartmental analysis in biology and medicine. J. A. Jacquez, ed. The University of Michigan Press, Ann Arbor.

Kertz, A. F. 1998. Variability in delivery of nutrients to lactating dairy cows. J. Dairy Sci. 81:3075-3084.

Klausner, S. D., D. G. Fox, C. N. Rasmussen, R. E. Pitt, T. P. Tylutki, P. E. Wright, L. E. Chase, and W. C. Stone. 1998. Improving dairy farm sustainability I: An approach to animal and crop nutrient management planning. J Prod. Agric. 11:225-233.

Kohn, R. A., and M. S. Allen. 1995. In vitro protein degradation of feeds using concentrated enzymes extracted from rumen contents. Anim. Feed Sci. Technol. 52:15-28.

Kohn, R. A., K. F. Kalscheur, and M. Hanigan. 1998. Evaluation of models for balancing the protein requirements of dairy cows. J. Dairy Sci. 81:3402-3414.

Lagunes, F. I. J., D. G. Fox, R. W. Blake, and A. N. Pell. 1999. Evaluation of tropical grasses for milk production by dual-purpose cows in tropical Mexico. J. Dairy Sci. 82:2136-2145.

Law, A. M., and W. D. Kelton. 2000. Simulation modeling and analysis. 3rd ed. Tata McGraw-Hill Publishing Company, New Delhi, India.

Lykos, T., and G. A. Varga. 1995. Effects of processing method on degradation characteristics of protein and carbohydrate sources in situ. J. Dairy Sci. 78:1789-1801.

Mahadevan, S., J. D. Erfle, and F. D. Sauer. 1980. Degradation of soluble and insoluble proteins by Bacteroides amylophilus protease and by rumen microorganisms. J. Anim. Sci. 50:723-728.
Matis, J. H., and H. D. Tolley. 1980. On the stochastic modeling of tracer kinetics. Fed. Proc. 39:104-109.

McKay, M. D., R. J. Beckman, and W. J. Conover. 1979. A comparison of three methods for selecting values of input variables in the analysis of output from a computer code. Technometrics $21: 239-245$.

Mowrey, A., and J. N. Spain. 1999. Results of a nationwide survey to determine feedstuffs fed to lactating dairy cows. J. Dairy Sci. $82: 445-451$.

Muscato, T. V., C. J. Sniffen, U. Krishnamoorthy, and P. J. Van Soest. 1983. Amino acid content of noncell and cell wall fractions in feedstuffs. J. Dairy Sci. 66:2198-2207.

Nakamura, T., T. J. Klopfenstein, and R. A. Britton. 1994. Evaluation of acid detergent insoluble nitrogen as an indicator of protein quality in nonforage proteins. J. Anim. Sci. 72:1043-1048.

Noftsger, S., and N. R. St-Pierre. 2003. Supplementation of methionine and selection of highly digestible rumen undegradable protein to improve nitrogen efficiency for milk production. J. Dairy Sci. 86:958-969.

Noziere, P., and B. Michalet-Doreau. 2000. In sacco methods. Pages 233-253 in Farm animal metabolism and nutrition. J. P. F. D'Mello, ed. CAB International, Wallingford, UK.

NRC. 1993. Soil and Water Quality: An agenda for agriculture. Natl. Acad. Press, Washington, DC.

NRC. 2001. Nutrient Requirements for Dairy Cattle. Natl. Acad. Press, Washington, DC.

NRC. 2003. Air Emissions from Animal Feeding Operations: Current Knowledge, Future Needs. Natl. Acad. Press, Washington, DC.

O'Connor, J. D., C. J. Sniffen, D. G. Fox, and W. Chalupa. 1993. A Net Carbohydrate and Protein System for evaluating cattle diets. 4. Predicting amino-acid adequacy. J. Anim. Sci. 71:1298-1311.

Offner, A., and D. Sauvant. 2004. Comparative evaluation of the Molly, CNCPS, and LES rumen models. Anim. Feed Sci. Technol. 112:107-130.

Orskov, E. R., and I. McDonald. 1979. The estimate of protein degradability in the rumen from incubation measurements weighted according to rate of passage. J. Agric. Sci. 92:499-503.

Ott, R. L., and M. Longnecker. 2001. An introduction to statistical methods and data analysis. 5th ed. Duxbury, Pacific Grove, CA.

Peltekova, V. D., and G. A. Broderick. 1996. In vitro ruminal degradation and synthesis of protein on fractions extracted from alfalfa hay and silage. J. Dairy Sci. 79:612-619.

Pichard, G. 1977. Forage nutritive value. Continuous and batch in vitro rumen fermenations and nitrogen solubility. $\mathrm{PhD}$ Diss., Cornell Univ., Ithaca, NY.

Reynal, S. M., and G. A. Broderick. 2003. Effects of feeding dairy cows protein supplements of varying ruminal degradability. J. Dairy Sci. 86:835-843.

Ross, D. A. 2004. Amino acid composition of ruminant feeds and feed fractions and evaluation of the methods used to obtain the insoluble and true precipitable protein fractions of feedstuffs. MS Thesis, Cornell Univ., Ithaca, NY.

Ruiz, R., L. O. Tedeschi, J. C. Marini, D. G. Fox, A. N. Pell, G. Jarvis, and J. B. Russell. 2002. The effect of a ruminal nitrogen (N) deficiency in dairy cows: Evaluation of the Cornell Net Carbohydrate and Protein System ruminal N deficiency adjustment. J. Dairy Sci. 85:2986-2999.

Russell, J. B. 1993. Effect of amino acids on the heat production and growth efficiency of Streptococcus bovis-Balance of anabolic and catabolic rates. Appl. Environ. Microbiol. 59:1747-1751.

Saltelli, A. 2000. What is sensitivity analysis? Pages 3-13 in Sensitivity analysis. A. Saltelli, K. Chan, and E. M. Scott, ed. John Wiley \& Sons, Chichester, NY.

Schroeder, G. E., L. J. Erasmus, K.-J. Leeuw, and H. H. Meissner. 1995. The use of acid detergent insoluble nitrogen to predict digestibility of rumen undegradable protein of heat processed plant proteins. S. Afr. J. Anim. Sci. 26:49-52.

Schwab, C. G., C. K. Bozak, N. L. Whitehouse, and M. M. A. Mesbah. 1992. Amino acid limitation and flow to duodenum at four stages of lactation. 1. Sequence of lysine and methionine limitation. J. Dairy Sci. 75:3486-3502. 
Schwab, C. G., P. Huhtanen, C. W. Hunt, and T. Hvelplund. 2005. Nitrogen requirements in cattle Pages 13-70 in Nitrogen and phosphorus nutrition of cattle. E. Pfeffer and A. Hristov, ed. CABI Publishing, Wallingford, UK

Seo, S., L. O. Tedeschi, C. Lanzas, C. G. Schwab, and D. G. Fox. 2006 Development and evaluation of empirical equations to predict feed passage rate in cattle. Anim. Feed Sci. Technol. 128:67-83.

Siddons, R. C., J. Paradine, D. E. Beever, and P. R. Cornell. 1985. Ytterbium acetate as a particulate-phase digesta flow marker $\mathrm{Br}$. J. Nutr. 54:509-519.

Tedeschi, L. O., D. G. Fox, and J. B. Russell. 2000. Accounting for the effects of a ruminal nitrogen deficiency within the structure of the Cornell Net Carbohydrate and Protein System. J. Anim. Sci. 78:1648-1658.

Tedeschi, L. O., A. N. Pell, D. G. Fox, and C. R. Llames. 2001. The amino acid profiles of the whole plant and of four plant residues from temperate and tropical forages. J. Anim. Sci. 79:525-532.

Tylutki, T. P. 2002. Improving herd nutrient management on dairy farms. PhD Diss., Cornell Univ., Ithaca, NY.
Van Soest, P. J. 1989. On the digestibility of bound $\mathrm{N}$ in distillers grains: A reanalysis. Pages 127-135 in Proc. Cornell. Nutr. Conf. Feed Manuf. Cornell University, Ithaca, NY.

Van Soest, P. J., C. J. Sniffen, D. R. Mertens, D. G. Fox, P. H. Robinson, and U. Krishnamoorthy. 1981. A net protein system for cattle: The rumen submodel for nitrogen. Protein requirements for cattle (MP109-P). Oklahoma State Univ., Stillwater, OK.

Van Kessel, J. S., and J. B. Russell. 1996. The effect of amino nitrogen on the energetics of ruminal bacteria and its impact on energy spilling. J. Dairy Sci. 79:1237-1243.

Waldo, D. R., L. W. Smith, and E. L. Cox. 1972. Model of cellulose disappearance from the rumen. J. Dairy Sci. 55:125-129.

Wattiaux, M. A., and K. L. Karg. 2004. Protein level for alfalfa and corn silage-based diets: II. Nitrogen balance and manure characteristics. J. Dairy Sci. 87:3492-3502.

Weiss, W. P. 1994. Estimation of Digestibility of Forages by Laboratory Methods. Pages 644-681 in Forage Quality, Evaluation, and Utilization. G. C. Fahey, M. Collins, D. R. Mertens, and L. E. Moser, ed. ASA, CSSA, and SSSA, Madison, WI. 